\title{
Morphology and formal description of Sellaphora bisexualis sp. nov. (Bacillariophyta)
}

\author{
David G. ManN*1, Katharine M. Evans ${ }^{1}$, Victor A. ChePuRnov ${ }^{2} \&$ Satoshi Nagai $^{3}$ \\ ${ }^{1}$ Royal Botanic Garden, Edinburgh EH3 5LR, Scotland, U.K.; *corresponding author e-mail: David G. Mann, \\ d.mann@rbge.org.uk \\ ${ }^{2}$ SBAE Industries NV, 9950 Waarschoot, Belgium \\ ${ }^{3}$ National Research Institute of Fisheries and Inland Sea, Maruishi 2-17-5, Hatsukaichi, Hiroshima 739-0452, \\ Japan
}

\begin{abstract}
Previous molecular genetic and life cycle studies have revealed the existence of a vigorously homothallic deme within the Sellaphora pupula species complex, which was given the provisional name of Sellaphora [pupula $\mathrm{K}-\mathrm{LB}] \Phi$ 'urban elliptical'. This is described here as $S$. bisexualis sp. nov., with a cox 1 DNA-barcoded type from Scotland. A detailed description of frustule ultrastructure is given, the most complete for a Sellaphora species. The morphology of the terminal raphe fissure is variable, becoming vestigial in some small pre-auxospore valves, and the boundary between the raphe-sternum and striae is sometimes strongly, sometimes weakly marked by larger areolae and an external groove. The cingulum contains at least three plain bands. The pars interior of band 1 (the valvocopula), as well as being undulate with a pitch corresponding to the transapical ribs, bears a very fine fringe of short fimbriae. Sexual reproduction involves 'male' and 'female' gametangia, as in other allogamous species of Sellaphora, but in S. bisexualis cells of the same clone can differentiate into either sex, allowing homothallic reproduction and successive inbred generations. The proven distribution of the species includes sites in the UK and Australia.
\end{abstract}

Key words: Bacillariophyta, biogeography, DNA barcode, diatoms, frustule, new species, taxonomy

\section{Introduction}

The genus Sellaphora was described by MERESCHKOWSKY (1902) and resurrected by MANN (1989), following studies of the frustules, plastids and auxosporulation. The taxonomic history, characteristics and diversity of the genus have recently been reviewed by MANN et al. (2008), who concluded that there are many more species within the genus than the c. 80 that currently have formal binomials. There is now abundant evidence of pseudocryptic species (MANN \& Evans 2008) within the genus, which, although minimally different morphologically, have distinct molecular signatures and when tested prove to be reproductively isolated (MANN et al. 2004, 2008, BeHNKE et al. 2004, Evans et al. 2007, 2008). The difficulty of using morphology for species discovery and identification led to the development of DNA barcoding for the genus, which is currently based on the mitochondrial cox 1 gene (Evans et al. 2007). Evans \& MANN
(2009) and JAHN et al. (2008) have used cox 1 barcodes to help standardize diatom taxonomy (as 'molecular types'), and Evans et al. (2009b) have applied barcoding to a specific problem, namely identification of $S$. capitata D.G. MANN et S.M. MCDONALD for microsatellite studies of gene flow. Given the problems of identification, it is highly desirable that all new Sellaphora species should be barcoded, although this may be impossible in some instances (e.g. fossil material).

MANN et al. (2008) catalogued the morphological diversity of the larger-celled Sellaphora species in the British Isles, referring to formally published species where possible and describing the remainder of the diversity as a series of 'demes', with informal names like 'tiny', 'elliptical' and 'lemon', usually referring to obvious features of their valve morphology. The demes are putative species, to be given formal status after further evaluation of the evidence for species separation (cf. DE QUEIROZ 2007). In one of these putative species, we consider that the 
evidence and documentation are now sufficient to justify description as a new species and, in this paper, we assign the name $S$. bisexualis to the diatom that was referred to as the 'urban elliptical' deme (in the $S$. pupula species complex) by MaNN et al. (2008); this formed part of the 'elliptical' deme in the publications of MANN (1999, p. 471) and Evans et al. (2007, 2008).

\section{Material and methods}

Mixed 'seminatural' populations of epipelon containing Sellaphora species were obtained from lakes and ponds in the United Kingdom and Australia. The methods of harvesting and processing epipelon have been described in detail by MANN et al. (2008), who also provided information on light microscopical (LM) methods and instrumentation. Most of the observations reported here were obtained from natural epipelon and clones from Blackford Pond, Dunsapie Loch, Lochend Loch, the main pond of the Royal Botanic Garden Edinburgh, and an old flax-retting moat in Balerno, all in Edinburgh, Scotland (UK National Grid References NT253708, NT280730, NT275747, NT248753, and NT167655 respectively); Lake Mumblin, Victoria, Australia $\left(38^{\circ} 19^{\prime} 08^{\prime \prime} \mathrm{S}, 142^{\circ} 54^{\prime} 52^{\prime \prime} \mathrm{E}\right)$; and Streeton Pond, Yallambie, Melbourne, Australia (MELWAY ref 20G9). Epipelon was cleaned by boiling in concentrated nitric and sulphuric acids. Cultured material was cleaned using 30-volume hydrogen peroxide. Microscope slide preparations are held in the diatom herbarium of the Royal Botanic Garden Edinburgh (E) and those used to prepare the plates are listed in the figure captions

Clones of S. bisexualis were isolated by streaking harvested epipelon on agar plates (WC medium solidified with $2 \%$ agar). After 2-3 weeks' incubation, cells were isolated from the margins of discrete, homogeneous colonies and transferred to liquid WC medium. They were subsequently maintained in 50 $\mathrm{mm}$ Petri dishes at $15-18^{\circ} \mathrm{C}$, with $10-14 \mathrm{~h}$ light per day (c. 5-20 $\mu \mathrm{mol}$ photons $\mathrm{m}^{-2} \mathrm{~s}^{-1}$ ). Cultures were inspected using an Axiovert inverted microscope (Carl Zeiss, Oberkochen, Germany).

For scanning electron microscopy (SEM), suspensions of cleaned diatoms were dried onto small round cover-slips, which were then attached to aluminium stubs by carbon tabs, with silver dag painted around the edges to promote electrical conduction. Stubs were coated with platinum for $2 \mathrm{~min}$ in an Emitech K575X sputter coater and examined using a LEO Supra 55VP Field Emission SEM operated at $5 \mathrm{kV}(4$ mm working distance; aperture $20 \mu \mathrm{m}$ ). Images (8-bit or 16-bit grayscale) were captured as $2048 \times 1536$ or $3702 \times 2304$ pixel TIFF files. LM micrographs taken on Kodak Technical Pan film (no longer manufactured) were digitized using a Nikon Super Coolscan 5000.

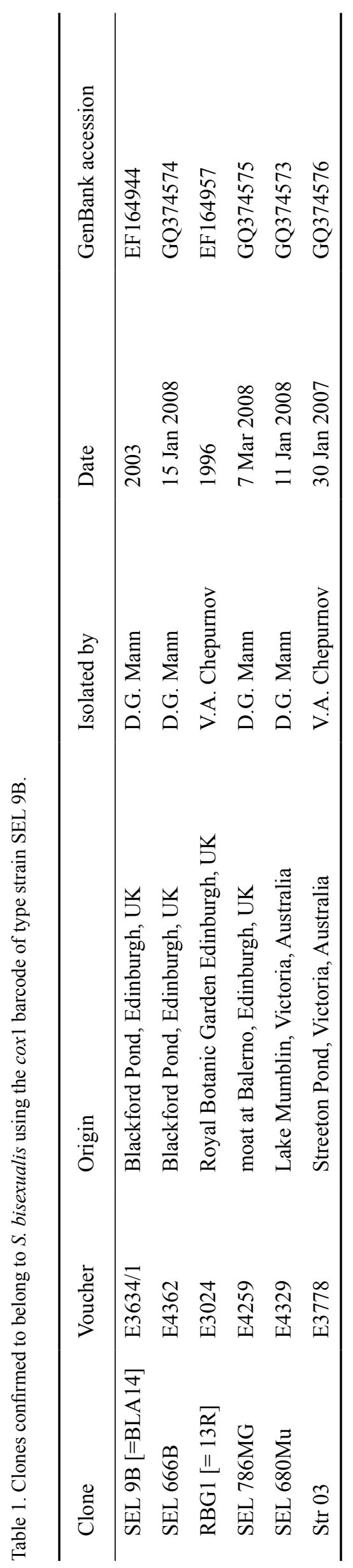


These and original digital images (from LM and SEM) were prepared for publications after general adjustment using the Levels, Curves and Brightness/Contrast tools (with very limited local burn-in) of Adobe Photoshop (Adobe CS2: www.adobe.com).

Cox 1 barcode sequences were obtained using the primers and protocols described by EvANs et al. (2007). For GenBank BARCODE records, more stringent requirements are in place (RATNASINGHAM \& HeBert 2007) and to meet these for clone SEL 9B (the type of $S$. bisexualis) we used the protocol described by Evans \& MANN (2009) to upgrade GenBank accession EF164944.

The use of formula names such as Sellaphora [pupula K-LB] $\Phi$ 'upland elliptical' to refer to informally named demes within a species complex is explained by MANN et al. (2008, p. 27).

\section{Results}

\section{Sellaphora bisexualis D.G. MANn et K.M. Evans sp. nov. (Figs 1-31)}

Synonyms: S. pupula 'elliptical' ex parte (MANN 1999, p. 471; Evans et al. 2007, 2008); S. pupula 'urban elliptical' (MANn et al. 2008, PoulíčKovÁ et al. 2008).

Valvae lineari-ellipticae, polis parum rostratis (valvis parvissimis exceptis), 20-55 $\mu \mathrm{m}$ longae, 6.75-9.0 $\mu \mathrm{m}$ latae. Striae rectae per LM velut irregulariter punctatae, centrum versus radiatae ad paene parallelae, prope polos parallelae vel aliquantum curvatae, interdum aliquot striis brevibus intercalaribus ad centrum, 18.521.5 in $10 \mu \mathrm{m}$. Areolae circulares hymenibus internis occlusae. Area axialis angusta. Area centralis valde expansa (ad 60-80\% latitudinis valvae), transverse rectangularis. Raphosternum plerumque sulco non profundo utrinque limitatum. Raphe leviter sinuosa, fissuris terminalibus curvatis (in speciminibus brevibus interdum nullis), extremis centralibus et externis et internis latus primarium versus flexis. Transtra polaria parallela, interdum paulum radiantia in speciminibus longis. Ex taeniis cingularis prima secundaque apertae sine poris, tertia etiam sine poris fortasse clausa; secunda segmentali.

Valves linear-elliptical with slightly rostrate poles (except in the smallest valves), 20-55 $\mu \mathrm{m}$ long, 6.75-9.0 $\mu \mathrm{m}$ wide (Figs 1-14). Striae straight, in LM apparently irregularly punctate, radiate to almost parallel centrally, parallel or slightly curved near the poles, sometimes with a few intercalated short striae at the centre, $18.5-21.5$ in $10 \mu \mathrm{m}$. Areolae circular (Figs 21-25), closed internally by hymenes (Fig. 28). Axial area narrow. Central area strongly expanded (to $60-80 \%$ of the valve width), transversely rectangular. Raphe-sternum usually bordered on either side by a shallow groove (Figs 22, 25). Raphe slightly sinuous (Figs 21,23 ), with curved terminal fissures (sometimes absent in short specimens) and central raphe endings that are bent towards the primary side both internally (Fig. 29) and externally (Fig. 25). Polar bars parallel, sometimes slightly radiate in long specimens (Figs 1-14). Out of the girdle bands, the first and second are open and nonporous, the third is also without pores and may be closed; the second is segmental (Figs 30, 31).

Holotype: Material of clone SEL 9B, as preserved on slide E3634/1 (E), illustrated in Figs 1-4 and 21-31, barcoded in GenBank accession EF164944 (cox 1 ), and with preserved DNA [at (E)] as EDNA 09-00352. Clone SEL 9B was isolated in April 2003 from a sample of epipelon collected at the SW end of Blackford Pond, Edinburgh (UK National Grid Reference NT 253708). Slide E3634/1 contains pre- and post-auxospore valves (Figs 3, 4 and 1, 2, respectively).

Derivation of the name: A single $S$. bisexualis clone is able to produce gametangia that behave as 'males' (producing active gametes) and gametangia that behave as 'females' (producing passive gametes); it is therefore bisexual.

Nomenclatural note: The previous informal name 'elliptical' was chosen for this species and a related one (the 'upland elliptical' deme of MANN et al. 2008) because of the shape of the valve, especially in cells towards the end of size reduction. It should be noted that there is no link between S. bisexualis and Navicula pupula var. elliptica Hust. (Hustedt 1911, p. 291, pl. 3, fig. 40) for which a type was selected and illustrated by SimONSEN 1987, pl. 5, figs 3, 4). SimONSEN's lectotype is compatible with HUSTEDT's original description and illustration and shows a diatom similar to Sellaphora auldreekie D.G. MANN et S.M. McDonald (ManN et al. 2004, ManN et al. 2008, fig. 34) or the 'tiny' deme (MANN et al. 2008, fig. 35) towards the end of size reduction; it has very slightly rostrate apices, and fine and clearly radiate striae. In contrast, the illustrations of var. elliptica by HustedT (1930, fig. 467d) and Hustedt (1961, fig. 1254h, as f. elliptica (Hust.) Hust.) show a diatom like $S$. bisexualis and $S$. [pupula $\mathrm{K}-\mathrm{LB}$ ] $\Phi$ 'upland elliptical' and this is probably the interpretation most people have adopted, incorrectly, during identification. For example, PAtrick \& Reimer (1966, pl. 47, fig. 11) 


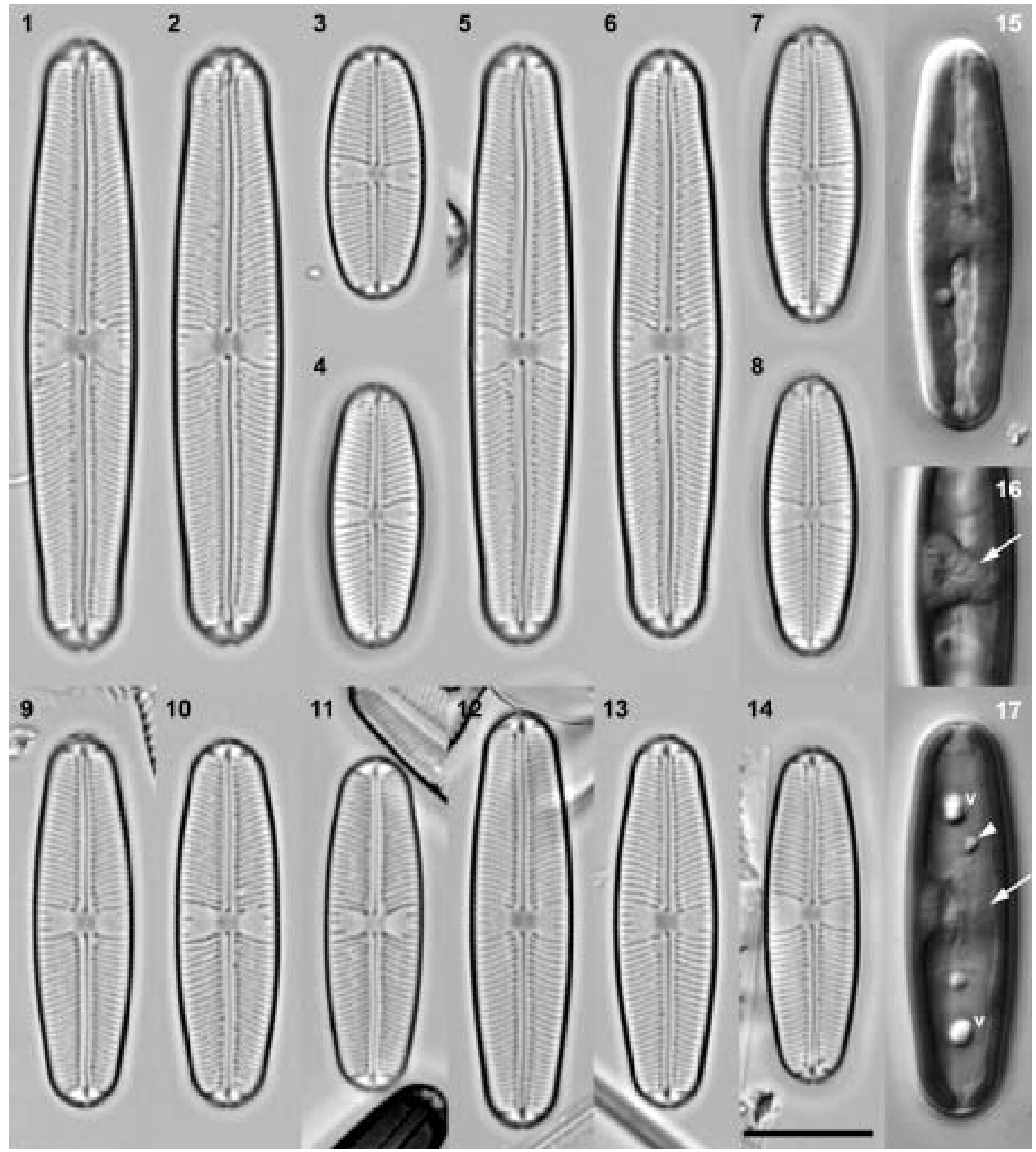

Figs 1-14. Sellaphora bisexualis valves, LM, bright field optics: (1-4) holotype slide E 3634/1: clone SEL 9B, from Blackford Pond; Figs (1, 2 and 3, 4) show post- and pre-auxospore valves, respectively; (5-8) clone SEL 7B on slide E3627/1, from Blackford Pond; (9) natural epipelon, Blackford Pond, on slide E3667/2; $(10,11)$ clones SEL 790MG and SEL 787MG, on slides E4262 and E4260, respectively; $(12,13)$ natural epipelon, Royal Botanic Garden Edinburgh pond, on slide E2614/2; (14) natural epipelon, Streeton Pond, Australia, on slide E3702/3. Scale bar $10 \mu \mathrm{m}$.

Figs 15-17. A single living cell from Lochend Loch, LM, differential interference contrast optics: (15) focus just beneath the epivalve, showing a single $\mathrm{H}$-shaped chloroplast; (16) detail of the invaginated tetrahedral pyrenoid (arrow); (17) focus near the hypovalve, showing the nucleus (centre, offset to the right) containing a single nucleolus (arrow), two volutin granules (v) and some extra granules (e.g. arrowhead) that may represent reserve material. Scale bar $10 \mu \mathrm{m}$.

illustrate a non-rostrate valve that corresponds closely to HustedT's 1930 illustration of var. elliptica and shows its striae not as simple lines but as having crenulate sides, as if composed of very closely spaced pores; this is what is seen in at least parts of the valves in $S$. bisexualis and $S$. [pupula K-LB] $\Phi$ 'upland elliptical'. However, PATRICK \& REIMER's interpretation of var. elliptica 


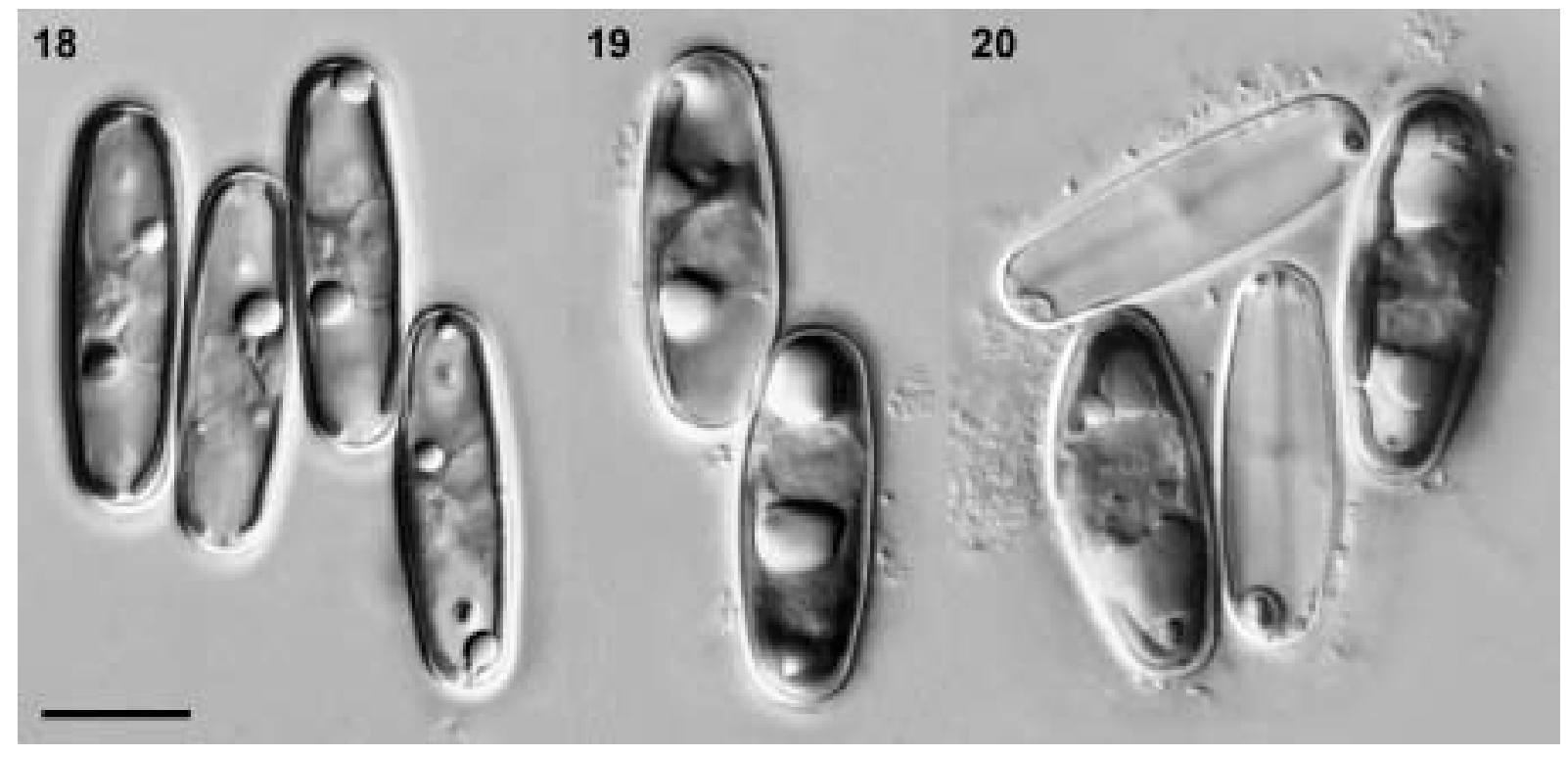

Figs 18-20. Sellaphora bisexualis, homothallic reproduction in clone 3R from the main pond, Royal Botanic Garden Edinburgh: living cells, LM, differential interference contrast optics: (18) quadruplet of copulating cells, before transition to meiosis (note unexpanded eccentric nuclei); (19) pair of gametangia in meiotic prophase. Note the enlarged, apparently spherical nuclei and displaced chloroplasts; (20) quadruplet that has resolved into two pairs, each of which has completed plasmogamy, creating two almost empty gametangia and two gametangia distended by the zygotes formed within them; note the ' $\mathrm{T}$ ' configuration of one gametangium relative to the three others. Scale bar $10 \mu \mathrm{m}$.

is incompatible with the type of elliptica chosen by SIMONSEN (op. cit.).

HusTEDT's variety was transferred to Sellaphora as Sellaphora elliptica (Hust.) J.R. JOHANSEN in J.R. JOHANSEN et al. (2004, p. 24). This was illegitimate, because MERESCHKOWSKY (1902,p. 190)hadalready used the name for a quite different species, from a marine lagoon in California. There is therefore no possibility of using 'elliptica' for $S$. bisexualis or $S$. [pupula K-LB] $\Phi$ 'upland elliptical', despite the descriptive value of the epithet and the likely precedents for identification of either or both species as the 'var. elliptica' or 'f. elliptica' of Sellaphora (Navicula) pupula. The identity of MereschKowsKY's $S$. elliptica is unknown and it may not even belong to Sellaphora.

Morphology and life history: The valves of S. bisexualis have a simple outline (Figs 1-14), being linear-elliptical with slightly rostrate poles in post-auxospore valves (Figs 1, 2, 5, 6) and medium-sized valves (Fig. 12), but becoming simply elliptical in the smallest valves (Figs 3,4). During sexual reproduction, gametangia of 20 $33 \mu \mathrm{m}$ give rise to initial cells of $50-55 \mu \mathrm{m}$ and this represents the range of size found in nature; however, in culture cells $<20 \mu \mathrm{m}$ long can be formed. Our unquantified impression is that long valves $(>40-45 \mu \mathrm{m})$, representing the earlier part of the life cycle, are commoner in natural $S$. bisexualis populations than the equivalent stages in heterothallic species such as S. capitata.

Living cells have the same structure as most other Sellaphora species (summarized by MANN 1989), having a single $\mathrm{H}-$ shaped chloroplast with its centre against the epivalve (Fig. 15), containing an invaginated tetrahedral pyrenoid on one side (Fig. 16). Opposite the pyrenoid and slightly closer to the hypovalve is an elongate nucleus in a bridge of cytoplasm (Fig. 17). Two volutin granules are present, and other granules and droplets may also be present (Fig. 17). Sexual reproduction is also like that seen in most other Sellaphora species (MANN 1989). Cells copulate laterally and enter meiotic prophase, during which the nucleus becomes markedly expanded and \pm spherical (Figs 18, 19). Each gametangium produces a single gamete, which can either be 'male' (active) or 'female' (passive). Movement of the male gamete into the female gametangium effects plasmogamy, leaving the male cells empty (Fig. 20), apart from the supernumerary cell produced at meiosis I and some residual cytoplasm from the male gamete. In S. bisexualis, sexual reproduction occurs within a single clone (the species is homothallic) and cells can differentiate either as males or as females, in contrast to an obligately heterothallic species like S. capitata, in which all cells within a clone (with very few exceptions) have the same sex. One 


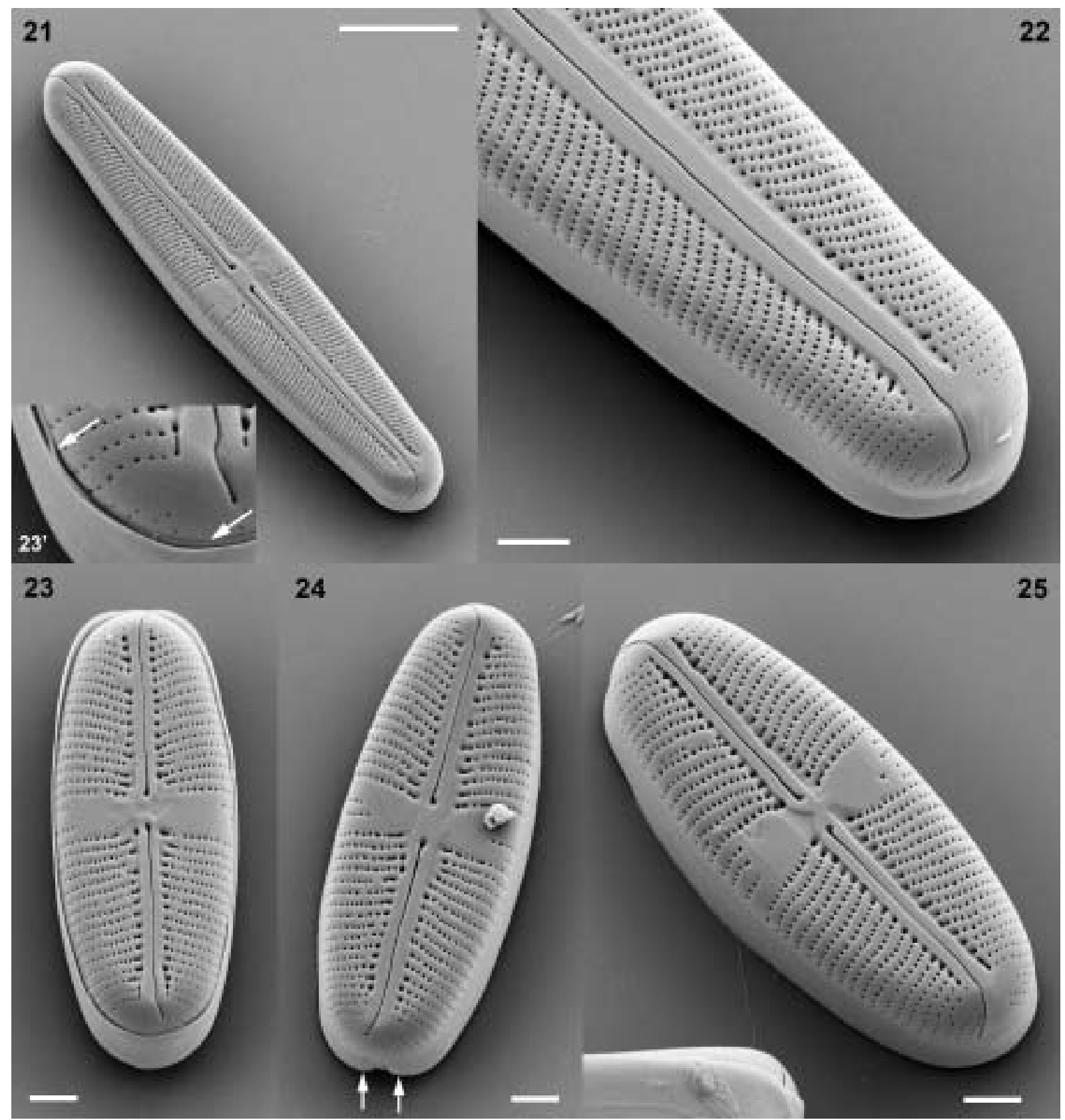

Figs 21-25. Sellaphora bisexualis, clone SEL 9B (type material), external views, SEM: (21) post-auxospore valve (cf. Figs $1,2)$, outside; (22) post-auxospore valve: detail of valve apex and terminal raphe fissure; $\left(23,23^{\prime}\right)$ pre-auxospore frustule, hypovalve uppermost, with (23') detail of the valve apex showing the narrow third band (arrows); (24) pre-auxospore valve with very short terminal fissures; note the open ends of the first band (arrows); (25) pre-auxospore valve with well differentiated raphe-sternum and long terminal fissures. Scale bars $10 \mu \mathrm{m}$ (Fig. 21 only) or $2 \mu \mathrm{m}$.

feature of $S$. bisexualis not seen in some other Sellaphora species is that it is common for cells to pair in loose configurations, with only small parts of the gametangia in contact, such as their tips (Fig. 19) or one tip, as in ' $\mathrm{T}$ ' configurations (Fig. 20). Expansion of the auxospore takes place parallel to the long axis of the female gametangium (not illustrated), as in other Sellaphora species (Mann 1989). Sellaphora bisexualis can be maintained for at least three sexual generations in culture, because of its homothally and apparent lack of inbreeding depression. However, meiotic recombination can occur during auxosporulation and re-isolation from a single cell is essential in older cultures if clonality is important.

The valves consist of a narrow raphesternum and uniseriate striae separated by narrow transapical ribs (Figs 21-25). At the centre, there is a wide area without areolae, which in some cases reaches almost to the edge of the valve 


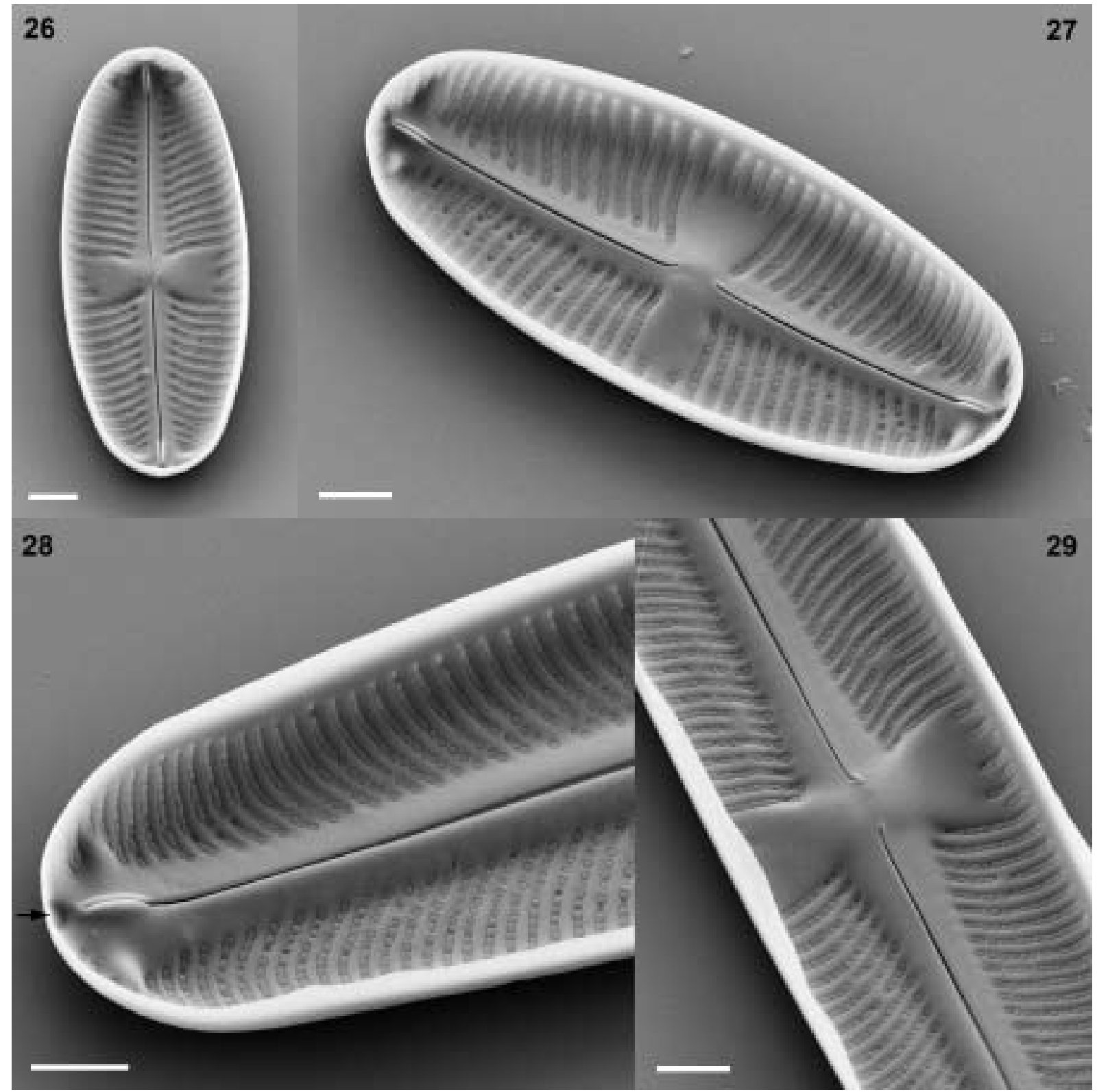

Figs 26-29. Sellaphora bisexualis, clone SEL 9B (type material), internal views, SEM: $(26,27)$ pre-auxospore valves, showing the very shallow boat-like shape and areolae with internal hymenes; (28) end of post-auxospore valve; note the elongate helictoglossa and nearby polar bars, and the apical pit (arrow); (29) centre, showing raphe endings deflected toward the primary side. Scale bars $2 \mu \mathrm{m}$.

face, resembling a fascia (Fig. 23). Externally, the raphe-sternum is usually delimited by a shallow groove, which can be well-developed (Figs 21, 22, 25) or barely perceptible (Fig. 24). The groove may pass across the central area without change (Fig. 21), or may expand to create 'haloes' around the central raphe endings (Figs 23, 25). Within the grooves, some areolae may merge externally to form larger depressions (Fig. 23) and this, together with the grooves themselves, creates a dark shadow along the edge of the raphe-sternum in LM (with the appropriate focus: Figs1-3, 5-10,
12, 13; compare Figs 21-23, 25).

Thereare 18.5-21.5 striae in $10 \mu \mathrm{m}$-less than in many Sellaphora species - containing circular areolae. The spacing of the areolae averages c. 40 in $10 \mu \mathrm{m}$, but it is irregular, creating places where the areolae are as much as $0.5 \mu \mathrm{m}$ apart (e.g. in Figs 23,24 ) and hence easily resolvable in LM, creating the appearance of irregular puncta. The striae continue uninterrupted across the valve face and down the shallow mantles (Figs 21-25), but stop well short of the valve margin (Figs 22, 25), except near the poles, where the plain marginal 


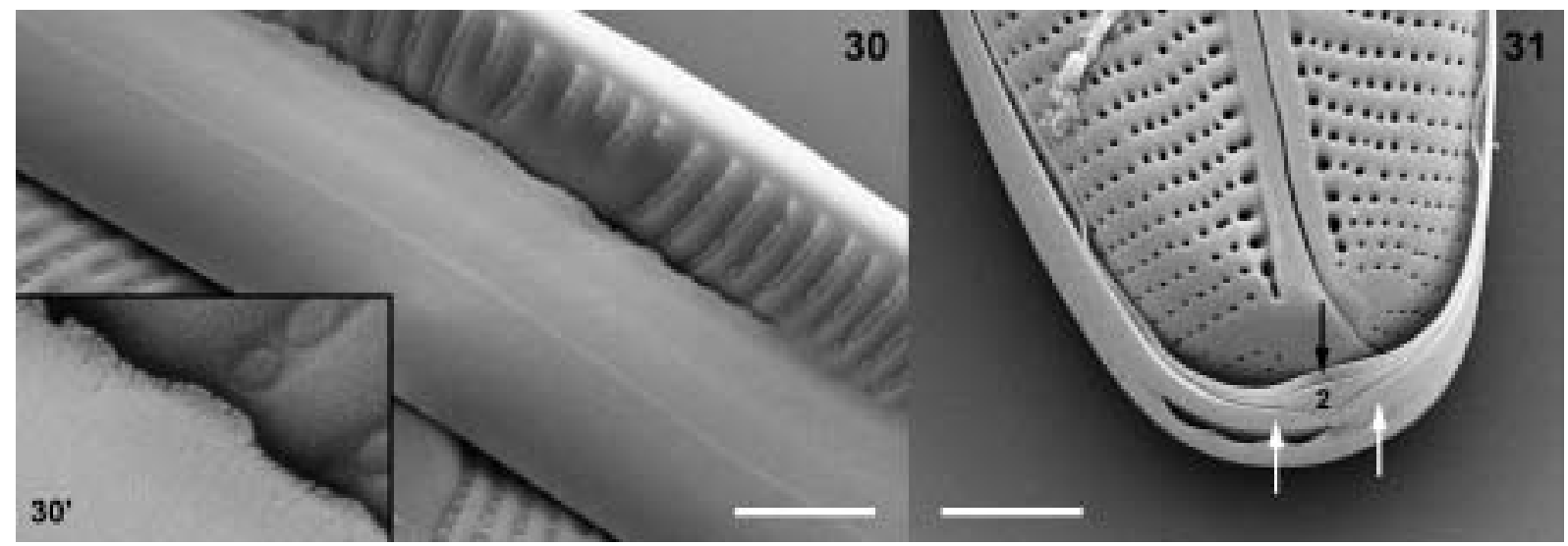

Figs 30, 31. Sellaphora bisexualis, clone SEL 9B (type material), SEM: (30, 30') part of band 1 (valvocopula) lying within a valve; inset $\left(30^{\prime}\right)$ shows the minutely fimbriate margin of the pars interior; (31) end of frustule, exterior (hypovalve uppermost), showing the open ends of band 1 (white arrows), the segmental band 2 (2) and the narrow centre of band 3 (black arrow). Scale bars $2 \mu \mathrm{m}$.

strip is much narrower (Fig. 28).

The areolae are not as prominent internally as externally, because each is occluded by a hymen at its inner aperture (Figs 26-29). The raphesternum is slightly thickened internally (Figs 27, 28), as is the fascia-like central area. At each pole, the raphe-sternum extends out laterally to form two polar bars (Figs 26-28), which are orientated at right angles to the raphe or slightly radiate (Figs 1-14). Beyond the helictoglossa, a small pit can often be seen internally (Fig 28, arrow), which has no obvious counterpart externally (Figs 22, 25).

The raphe slits are slightly sinuous (Figs 1-14), especially in longer valves (Fig. 21). The external central raphe endings are expanded into small rounded pores turned towards the primary side (Figs 21, 23-25). Internally (Figs 26, 27, 29) they are also turned towards the primary side but unexpanded. The terminal fissures of longer valves are long and curve towards the secondary side of the valve, with a slight inflection corresponding to the end of the helictoglossa (Figs 21, 22). In short valves, the terminal fissures may resemble those of long valves (Fig. 25), or can be reduced (Fig. 23) or virtually absent (Fig. 24). The helictoglossa is narrow and long (Figs 26-28).

The girdle consists of at least three bands. The first is wide and open (Figs 23, 24, 31). It has no pores, either in long cells (Fig. 30) or short (not illustrated) and its pars interior is almost entire, with very slight undulations corresponding to the valve striae and minute fimbriae on its margin (Fig. 30'). The second band is also nonporous and can be seen clearly at the end where band 1 is open (Fig. 31). There is also at least one other band, because in Fig. 31 a very narrow band can be seen beyond band 2. A similar narrow band can be seen in Fig. 23', beyond the closed end of band 1 but its nature cannot be established with certainty. It is unlikely to be part of band 2, because band 2 appears to be segmental, existing only at the end where band 1 is open and functioning to close the gap left by band 1 , and because band 2 might be expected to be open at the end where band 1 is closed (i.e. at the end shown in Fig. 23'). Our preliminary interpretation is that there are four bands in the mature cingulum: a wide band 1 , a segmental band 2, and two further, very narrow bands, corresponding to the strips visible in Figs $23^{\prime}$ and 31 , respectively.

Distribution: Morphology-based identifications of Sellaphora bisexualis have been made thus far only from eutrophic lowland ponds and lakes, growing in the epipelon of marginal mud (MANN et al. 2008, as 'urban elliptical'). We used the cox 1 barcode of the type clone (SEL 9B) to check morphology-based identifications of clones from the UK and Australia. Among these there was much more cox 1 variation ( 8 bp in c. 620 ) than was recorded in S. capitata by Evans et al. (2009) from different continents (which were identical apart from $1 \mathrm{bp}$ in one clone). The significance of this variation needs to be checked further, using other genes, morphometrics and mating studies, and it may reveal further cryptic speciation. Meanwhile, we accepted as confirmed identifications those clones whose sequences differ from SEL 9B by up to $2 \mathrm{bp}$ in c. 620. These are listed in Table 1, which demonstrates that $S$. bisexualis occurs in Australia and Europe. 


\section{Discussion}

The LM appearance of Sellaphora species allowed $19^{\text {th }}$ and $20^{\text {th }}$ century diatomists to distinguish several fairly distinct morphologies, which were usually recognized as single species. The most important of these were Navicula americana Ehrenb., N. bacillum EhrenB., N. pupula Kütz. and $N$. laevissima KüTz., all subsequently transferred to Sellaphora (MANN et al. 2008). All four of these are in fact heterogeneous, comprising several or many species (Evans et al. 2007, 2008, MANN et al. 2008), and at least one ( $S$. pupula) is not monophyletic (Evans et al. 2008). Nevertheless, for cataloguing and identification, the four morphologies constitute a useful descriptive framework, together with a group for 'small-celled' species such as $S$. seminulum (Grun.) D.G. ManN and S. disjuncta (Hust.) D.G. Mann. Sellaphora bisexualis belongs in the pupula group, because of its possession of polar bars (not present in the americana and laevissima groups) and transversely rectangular central area (not present in the bacillum group). The pupula group varies very widely but subtly in outline, size and valve pattern, and differential morphological diagnosis of the component species is extremely difficult; recognition is achieved most easily by visual comparisons (e.g. via MANN et al. 2008) and checks of valve width and stria density. In the case of $S$. bisexualis and some similar species, the coarse striae (c. 20 in $10 \mu \mathrm{m}$ ) and partial visibility of the areolae are useful extra characters in LM.

None of the ultrastructural features found in S. bisexualis are unique to it. All currently known Sellaphora species have simple uniseriate striae (except the seminulum group, where they are biseriate: Schoeman \& ARchiBAld 1976-80), and the areolae are apparently always simple round poroids with hymenes at their inner apertures (e.g. MAnN 1989, ManN et al. 2004). Grooves alongside the raphe-sternum externally are common in the pupula group, being illustrated for various species by LANGe-Bertalot et al. (2003, pl. 19), ManN et al. (2004), Metzeltin et al. (2005, pl. 69) and others. Some species have conopea externally, adjacent to the raphe-sternum, but many do not (e.g. Mann 1989, Mann et al. 2004, Levkov et al. 2007), as in S. bisexualis. The central raphe endings are apparently uniform within the genus, in being deflected towards the primary side and slightly to strongly expanded externally. The shape of the terminal fissure seems to vary among species
(MANN et al. 2004), but our data on variation within the type clone of $S$. bisexualis suggests that this character may be less reliable than we previously believed. The elongate helictoglossa is found throughout the pupula and bacillum groups (e.g. Mann 1989, ManN et al. 2004, Levkov et al. 2007), but not in some of the small-celled species (e.g. Lange-Bertalot et al. 2003, pl. 20). The small pit above the helictoglossa in $S$. bisexualis is also not unique, having been recorded in $S$. krsticii Levkov, Nakov et Metzeltin, $S$. ohridana Levkov et Krstic and $S$. lambda (Cleve) Metzeltin et Lange-Bert. (Levkov et al. 2007). These three species belong to the bacillum group, judging by valve shape and the structure of the axial area (which has a conopeum continuous from pole to pole) and if so, they are not closely related to $S$. bisexualis (Evans et al. 2007, 2008). Other members of the bacillum and pupula groups (which together comprise a clade according to molecular data: Evans et al. 2008) may therefore also possess pits, but the orientation of specimens in SEM is often unsuitable for detecting them, e.g. in the strictly vertical orientations used by MANN et al. (2004). Further studies are necessary.

Our study of the girdle still leaves its structure incompletely known, but it is now clear that there are at least three bands in a mature cingulum, rather than the two recorded by MANN (1989). Round et al. (1990) stated that four bands are present in the cingulum of $S$. bacillum (EhrenB.) D.G. ManN. In S. bisexualis, the bands are certainly nonporous, as claimed for the whole genus by ManN (1989), but we (A. Poulíčková \& D.G. Mann) now have data on another member of the S. pupula-bacillum clade that demonstrates a single line of pores in the pars exterior of band 1 .

Sellaphorabisexualis alsoexhibitsnounique characteristics in the structure of living cells and the mode of sexual reproduction. The chloroplast structure is typical of all Sellaphora species studied to date (e.g. MANN 1989), and the only slightly unusual feature of sexual reproduction is the variability of the pairing configuration, which varies from side-to-side (as in most other species) to T-shaped and end-to-end. However, even this characteristic is found in some other demes (our unpublished data), as is homothally.

Altogether, the lack of any qualitative (i.e. presence-absence) autapomorphies for $S$. bisexualis, together with the proven significance of very subtle differences in morphology as markers of species separation (Evans et al. 2007, 2008, 
MANN et al. 2008), leads us to recommend that, wherever possible, identification of $S$. bisexualis and most other Sellaphora species should be confirmed by molecular data, using a barcode approach. At the moment, this is best achieved using the cox 1 barcode we specify here; however, agreement has yet to be reached on whether cox 1 is a suitable barcode for all diatoms (Evans et al. 2007, Moniz \& Kaczmarska 2009).

We have now shown, using barcode-verified identifications, that two Sellaphora species $-S$. capitata and S. bisexualis - have genuinely wide distributions (Evans \& MANn 2009, Evans et al. 2009 , this paper). In both cases, exactly the same barcode sequence has been recovered from the UK and Australia (except for SEL 9B, all the clones listed in Table 1 have identical barcode sequences, differing from SEL 9B at two sites). Hence, some diatom species may indeed be widely and rapidly dispersed, as suggested for all protists by B.J. FinLAY and colleagues (e.g. FinLAY et al. 2004). However, this does not appear to be associated with a low global number of species, in contrast to another of FinLAY et al.'s assertions, raising the possibility that speciation of diatoms is often essentially sympatric, or that allopatric speciation is not prevented by rapid dispersal because genetic divergence and speciation are even faster. It is also possible, of course, that present distributions of freshwater diatoms have been significantly altered by human activity.

\section{Acknowledgements}

We thank Frieda Christie for help in preparing SEM specimens and for training David Mann to use the LEO Supra; Ruth McGregor for obtaining the upgraded barcode sequence of SEL 9B; and the Royal Society for an equipment grant to purchase a Polyvar photomicroscope. This work was in part supported by a Natural Environment Research Council Fellowship (NE/C518373/1) to Katharine Evans. We dedicate this paper to RNDr. Petr Marvan CSc., for his contributions to phycology.

\section{References}

Behnke, A., Friedl, T., Chepurnov, V.A. \& Mann, D.G. (2004): Reproductive compatibility and rDNA sequence analyses in the Sellaphora pupula species complex (Bacillariophyta). - J. Phycol. 40: 193-208.

DE QueIroz, K. (2007): Species concepts and species delimitation. - Systematic Biology 56: 879-
886.

Evans, K.M. \& MAnN, D.G. (2009): A proposed protocol for nomenclaturally effective DNA barcoding of microalgae. - Phycologia 48: 70-74.

Evans, K.M., Wortley, A.H. \& Mann, D.G. (2007): An assessment of potential diatom "barcode" genes (cox $1, r b c \mathrm{~L}, 18 \mathrm{~S}$ and ITS rDNA) and their effectiveness in determining relationships in Sellaphora (Bacillariophyta). - Protist 158: 349-364.

Evans, K.M., Wortley,A.H., Simpson, G.E., Chepurnov, V.A. \& MANn, D.G. (2008): A phylogenetic approach to explore the nature of cryptic diversity within the model species complex Sellaphora pupula agg. (Bacillariophyta). - J. Phycol. 44: 215-231.

Evans, K.M., Chepurnov, V.A., Sluiman, H.J., Thomas, S.J., Spears, B.M. \& Mann, D.G. (2009): Highly differentiated populations of the freshwater diatom Sellaphora capitata suggest limited dispersal and opportunities for allopatric speciation. - Protist 160: 386-396.

Finlay, B.J., Esteban, G.F. \& Fenchel, T. (2004): Protist diversity is different?. - Protist 155: 15-22.

Hustedt, F. (1911): Beiträge zur Algenflora von Bremen. IV. Bacillariaceen aus der Wümme. Abh. Naturw. Ver. Bremen 20: 257-315.

Hustedt, F. (1930): Bacillariophyta. - In: PAscher, A. (ed.): Die Süsswasser-Flora Mitteleuropas, vol. 10 (ed. 2). - 466 pp., G. Fischer, Jena.

Hustedt, F. (1961): Die Kieselalgen Deutschlands, Österreichs und der Schweiz unter Berücksichtigung der übrigen Länder Europas sowie der angrenzenden Meeresgebiete. - In: Dr L. Rabenhorsts (ed.): Kryptogamenflora von Deutschland, Österreich und der Schweiz, vol. 7(3:1). - pp. 1-160, Akademische Verlagsgesellschaft, Leipzig.

Jahn, R., Mann, D.G., Evans, K.M. \& PoulíčKová, A. (2008). The identity of Sellaphora bacillum (Ehrenberg) D.G. Mann. - Fottea 8: 121-124.

Johansen, J.R., Lowe, R., Gomez, S.R., Kociolek, J.P. \& Makosky, S.A. (2004): New algal species records for the Great Smoky Mountains National Park, U.S.A., with an annotated checklist of all reported algal species for the park. - Arch. Hydrobiol., Supplement 150 (Algological Studies 111): 17-44.

Lange-Bertalot, H., Cavacini, P., Tagliaventi, N. \& Alfinito, S. (2003): Diatoms of Sardinia. Rare and 76 new species in rock pools and other ephemeral waters. - In: LANGe-Bertalot, H. (ed.): Iconographia diatomologica. Annotated diatom micrographs, vol. 12. - 438 pp., Biogeography-Ecology-Taxonomy. - A.R.G. Gantner, Ruggell, Liechtenstein.

Levkov, Z., Krstic, S., Metzeltin, D. \& Nakov, T. 
(2007): Diatoms of lakes Prespa and Ohrid. About 500 taxa from ancient lake system. In: LANGe-Bertalot, L. (ed.): Iconographia diatomologica. Annotated diatom micrographs, vol. 16. - 611 pp., Biogeography-EcologyTaxonomy. - A.R.G. Gantner, Ruggell, Liechtenstein.

Mann, D.G. (1989): The diatom genus Sellaphora: separation from Navicula. - Br. Phycol. J. 24: $1-20$.

Mann, D.G. (1999): The species concept in diatoms (Phycological Reviews 18). - Phycologia 38: 437-495.

Mann, D.G. \& Evans, K.M. (2008): The species concept and cryptic diversity. - In: Moestrup, $\varnothing$. et al. (eds): Proceedings of the $12^{\text {th }}$ International Conference on Harmful Algae. - pp. 262-268, International Society for the Study of Harmful Algae and Intergovernmental Oceanographic Commission of UNESCO, Copenhagen.

Mann, D.G., McDonald, S.M., Bayer, M.M., Droop, S.J.M., Chepurnov, V.A., LoKe, R.E., Ciobanu, A. \& DU BuF, J.M.H. (2004): Morphometric analysis, ultrastructure and mating data provide evidence for five new species of Sellaphora (Bacillariophyceae). - Phycologia 43: 459482.

Mann, D.G., Thomas, S.J. \& Evans, K.M. (2008): Revision of the diatom genus Sellaphora: a first account of the larger species in the British Isles. - Fottea 8: 15-78.

Mereschkowsky, C. (1902): On Sellaphora, a new genus of diatoms. - Ann. Mag. Nat. Hist., series 7, 9: 185-195.
Metzeltin, D., Lange-Bertalot, H. \& GarcíaRodríguez, F. (2005): Diatoms of Uruguay. Compared with other taxa from South America and elsewhere. - In: LANGe-Bertalot, H. (ed.): Iconographia diatomologica. Annotated diatom micrographs. Vol. 15. - 736 pp., TaxonomyBiogeography-Diversity. A.R.G. Gantner, Ruggell, Liechtenstein.

Moniz, M.B.J. \& KaczmarskA, I. (2009): Barcoding diatoms: Is there a good marker? - Mol. Ecol. Res. 9 (suppl. 1): 65-74.

Patrick, R.M. \& Reimer, C.W. (1966): The diatoms of the United States, exclusive of Alaska and Hawaii. Vol. 1: Fragilariaceae, Eunotiaceae, Achnanthaceae, Naviculaceae. - Monogr. Acad. Nat. Sci. Philad. 13: 1-688.

PoulíčKovÁ, A., ŠpaČKovÁ, J., Kelly, M.G., Duchoslav, M. \& ManN, D.G. (2008): Ecological variation within Sellaphora species complexes (Bacillariophyceae) - specialists or generalists? - Hydrobiologia 614: 373-386.

Ratnasingham, S. \& Hebert, P.D.N. (2007): BOLD: The Barcode of Life Data System (www. barcodinglife.org). - Mol. Ecol. Notes 7: 355364.

Round, F.E., Crawford, R.M. \& Mann, D.G. (1990): The diatoms. Biology and morphology of the genera. - 747 pp., Cambridge University Press, Cambridge.

Schoeman, F.R. \& Archibald, R.E.M. (1976-1980): The diatom flora of southern Africa. - CSIR Special Report WAT 50, Pretoria, South Africa.

Simonsen, R. (1987): Atlas and catalogue of the diatom types of Friedrich Hustedt. 3 vols. - J. Cramer, Berlin \& Stuttgart.

(C) Czech Phycological Society

Received April 30, 2009

Accepted Jun 1, 2009 


\section{BOOK REVIEW}

\section{Hindák, F. (2009): Colour Atlas of Cyanophytes.}

- 253 pp., 805 figs, Veda, Bratislava.

Research into the Cyanobacteria continues apace and the appearance of new books and papaers continues to add to our knowledge of this group. Studies in the taxonomy, physiology, ecology and molecular biology of the cyanobacteria continue to reveal new information about this intriguing group of microscopic organisms and to raise new questions to be answered.

The author of this book, Prof. RNDr. František Hindák, DrSc. is one of the most experienced traditional phycologists and is the author of numerous scientific papers and books focused on the morphology and ecology of cyanobacteria and green algae. Throughout his career he paid special attention to the planktonic cyanobacteria and algae of the Morava and Danube rivers and their flood plain areas. Prof. Hindák has described numerous new species and genera of Cyanophytes and is regarded as a leading international authority on this group of

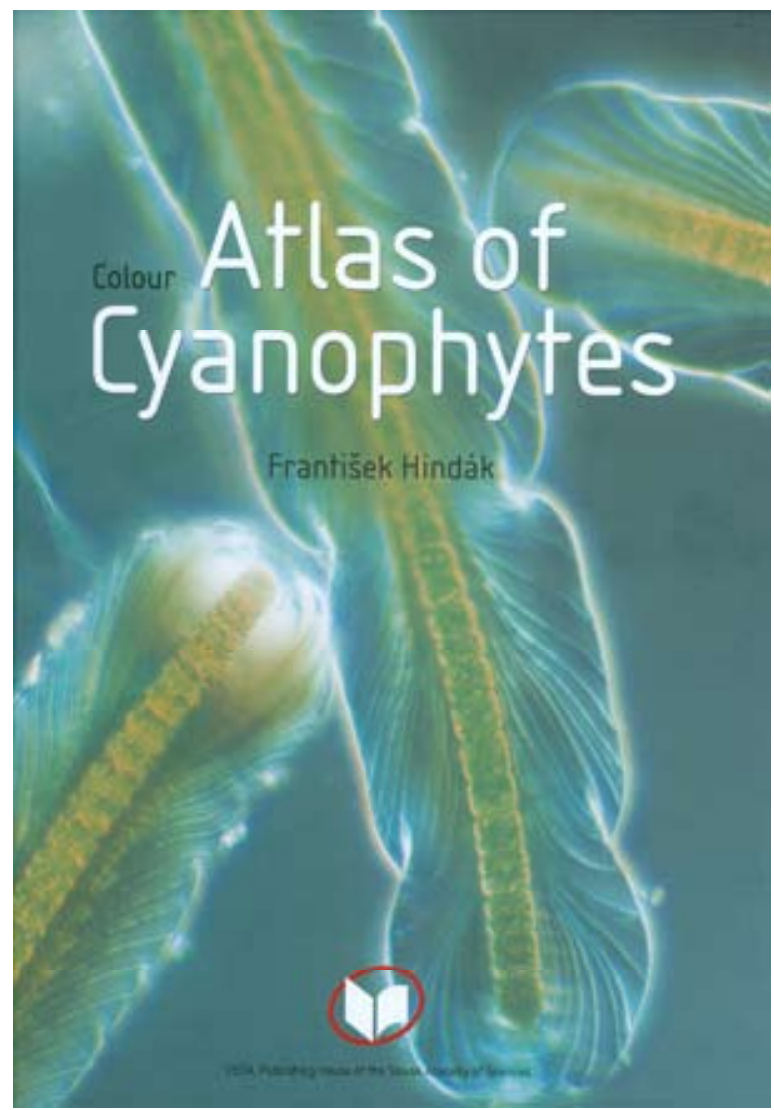
organisms.

His new book Colour Atlas of Cyanophytes, written in English, is therefore particularly welcome and follows successful publication of Fotografický atlas mikroskopických siníc (in Slovak, 2001), which unfortunately is currently out of print. This new work by the author includes a large body of useful information. Twenty-two pages are devoted to a description of the basic methods used in the study of cyanobacteria, followed by a short glossary, a taxonomic overview and a key to the documented orders and genera. The taxonomic treatment in the book is based on the approach recommended by KOMÁREK and Anagnostidis (1986, 1988, 1989, 1990, 1998, 2005). The longest (208 pages) and most valuable chapter in the book is a collection of fine colour microphotographs, documenting almost 269 coccal and filamentous cyanobacteria, the first of which was taken some 20 years ago, when the book was first conceived by Prof. Hindák. More than 20 years has gone since first snap when prof. decides to publish this book. His encyclopaedic knowledge of the life histories of the cyanobacteria and his undoubted enthusiasm for cyanobacterial research, is evident from the value and quality of these microphotographs. Both well known and less studied taxa are included. I particularly welomed the inclusion of excellent microphotographs of the very small chroococcalean and thin filamentous genera and species, which contain much detail of, for example, such groups as Cyanocatena, Cyanodictyon, Cyanogranis, Cyanonephron, Leibleinia, Mantellum, Planktolyngbya, Pannus). The author's great attention to detail has resulted in plates of considerable scientific value which will be of much assistance to both beginners and advanced phycologists studying the same groups, or wishing for a standard with which to compare their own samples.

The book is prepared to a very high standard by Prof. Hindák and his editor. In this occasion, I would like to point out both reviewers (Prof. RNDr. Jiří Komárek, DrSc. and RNDr. Jarmila Makovinská, Ph.D.), who guarantee a high standard of the publication. The book is a „must“ on any shelf of phycological books and I warmly recommend this book to all interested in the cyanobacteria and their mysterious life. 